Alon Segev

Thinking and Killing 



\section{Alon Segev}

Thinking

and Killing

Philosophical Discourse in the Shadow of the Third Reich

\section{DE GRUYTER}


ISBN 978-1-61451-128-1

e-ISBN 978-1-61451-101-4

\section{Library of Congress Cataloging-in-Publication Data}

A CIP catalog record for this book has been applied for at the Library of Congress.

\section{Bibliografische Information der Deutschen Nationalbibliothek}

The Deutsche Nationalbibliothek lists this publication in the Deutschen Nationalbibliografie; detailed bibliographic data are available in the internet http://dnb.dnb.de.

(c) 2013 Walter de Gruyter, Inc., Boston/Berlin

Typesetting: Frank Benno Junghanns, Berlin

Printing: Hubert \& Co. GmbH \& Co. KG, Göttingen

(2) Printed on acid-free paper

Printed in Germany

www.degruyter.com 